\title{
Multiple Ligament Knee Injuries
}

Editors

BRUCE A. LEVY

BENJAMIN FREYCHET

\section{CLINICS IN \\ SPORTS MEDICINE}

www.sportsmed.theclinics.com

Consulting Editor

MARK D. MILLER

April 2019 • Volume 38 - Number 2 